\title{
Prognosis in familial non-polyposis colorectal cancer
}

\author{
F Kee, B J Collins, C C Patterson
}

\begin{abstract}
Familial cases of non-polyposis colorectal cancer have attracted much interest but little is known of their natural history. Using a population based study we have determined whether a positive family history of bowel cancer is an independent prognostic factor. All patients under 55 years with histologically confirmed colorectal cancer in Northern Ireland during the period 1976-8 were studied. The family history was validated in $95 \%$ of all nonpolyposis cases $(n=205)$. Medical history or cause of death were verified for $98 \%$ of 1811 first degree relatives. The strength of the family history was assessed using a score that compares the mortality from bowel cancer in the family against the average population mortality, taking account of family size and age structure. The family history score was not predictive of survival neither in univariate analysis or in a Cox's proportional hazards multivariate analysis controlling for age, sex, stage, site, and duration of symptoms. In conclusion, a positive family history does not independently influence prognosis in patients with bowel cancer.
\end{abstract}

There is growing interest in refining methods for predicting prognosis in colorectal cancer based on the particular genotypical characteristics of individual tumours. ${ }^{1}$ Furthermore, it has recently been suggested that the clinical courses of hereditary and sporadic cancers may differ, ${ }^{23}$ and prolonged survival has been proposed as a feature of the "cancer family syndrome." $2-4$

To improve the stratification of patients into risk categories and subgroups for treatment, a knowledge of the family history may be advised. ${ }^{235}$ Because current evidence is based predominantly on patients referred to specialist centres, and in some instances on unsubstantiated family histories, ${ }^{5}$ however, the finding of improved survival in some reported cases of familial bowel cancer may be unrepresentative of the overall pattern.

The objective of this study was to determine whether the prognosis differed between familial and non-familial colorectal cancer in a population based sample of all histologically diagnosed cases in Northern Ireland.

\section{Methods}

\section{PATIENTS}

All patients in Northern Ireland who were histologically diagnosed as having colorectal cancer between 1976 and 1978 and who were under 55 years of age at the time of diagnosis were selected as probands. Hospital charts were reviewed and clinical details of age, sex, duration of symptoms, date of operation, family history, and tumour site and stage (Dukes' classification) were extracted. The patients' current condition was initially established through the original general practitioner and hospital consultant, and the death certificate was obtained for each deceased patient.

\section{FAMILY ASCERTAINMENT}

With ethical committee approval, the surviving patient or the next of kin was contacted and a home interview conducted to establish the name, address, and vital status of each first degree relative. The master patient index of the central services agency (the local family practitioner committee) was used to trace the usual general practitioner of those relatives resident in Northern Ireland. Their general practitioners were informed of the purpose of the study and asked to provide details of any history of malignancy or bowel disease in their patient. We conducted a postal survey of the first degree relatives living outside Northern Ireland, in which they were asked to give details of any personal medical history of malignancy, bowel disease, or surgery. If such a history was obtained, the relevant hospital charts (or cancer registration particulars) were reviewed.

Cause of death for each first degree relative was established using death certificates and this was subsequently compared with the history obtained from the medical chart or at interview.

\section{ANALYSIS}

Associations between the covariates (age, sex, duration of symptoms, family history, and tumour site and stage) were initially investigated with the $\chi^{2}$ test for contingency tables. Preliminary univariate analysis of the effect of each covariate on survival was carried out using the log rank test. ${ }^{6}$ The influence of a positive family history (of colorectal cancer in a first degree relative) on the prognosis of the index case was investigated fully using the Cox's proportional hazards method. ${ }^{7}$

TABLE I Accuracy of reported cause of death among first degree relatives according to type of cancer (colorectal cancer $\mathrm{v}$ all other cancer)

\begin{tabular}{|c|c|c|c|c|c|c|}
\hline & \multicolumn{2}{|c|}{$\begin{array}{l}\text { Type correctly } \\
\text { reported }\end{array}$} & \multicolumn{2}{|c|}{$\begin{array}{l}\text { Type } \\
\text { incorrectly } \\
\text { reported }\end{array}$} & \multicolumn{2}{|l|}{$\begin{array}{l}\text { Row } \\
\text { total }\end{array}$} \\
\hline & $\overline{N o}$ & $(\%)$ & No & $(\%)$ & No & $(\%)$ \\
\hline $\begin{array}{l}\text { All other cancer } \\
\text { Colorectal cancer } \\
\text { Column total }\end{array}$ & $\begin{array}{l}56 \\
34 \\
90\end{array}$ & $\begin{array}{l}(51) \\
(76) \\
(58)\end{array}$ & $\begin{array}{l}53 \\
11 \\
64\end{array}$ & $\begin{array}{l}(49) \\
(24) \\
(42)\end{array}$ & $\begin{array}{r}109 \\
45 \\
154^{\star}\end{array}$ & $\begin{array}{l}(100) \\
(100) \\
(100)\end{array}$ \\
\hline
\end{tabular}

Degrees of freedom $=1$.

$\chi^{2}$ for difference in proportions $=6.7 ; p<0.01$

$\star$ Six individuals who had verified cancer during life had a noncancer cause coded on the death certificate. 
The strength of the family history was rated using two methods, each of which takes some account of the age of the relative at diagnosis and of the family size. (The genetic contribution to disease in the young is thought greater than in older patients, and any definition of familiality in small kinships is more subject to the vagaries of chance.)

The first method, used initially by Lynch to subdivide heterogeneous groups of families into risk categories, ${ }^{8}$ compares the observed number of cases in a family (living and deceased) with the number expected, on the basis of the distribution of observed cases in all families across birth cohorts and age groups for all families in the sample. ${ }^{8}$

The second method, as originally described by Williams et al,,$^{910}$ is based on a comparison of the observed colorectal cancer deaths in a family with the number expected during the observation period, assuming that families experienced the mortality rates of the general population. To allow for any secular trends in cancer mortality, the expected deaths have been calculated using the person-years approach ${ }^{11}$ based upon the relevant age and sex specific death rates for colorectal cancer in Northern Ireland for seven consecutive quinquiennia since 1950 .

For both methods the strength of the family history was obtained as:

\section{$\mathrm{Z}=$ (observed - expected)/expected $\sqrt{\text { expected }}$}

The reader is referred to the original papers for the details of the calculation.

\section{Results}

\section{ASCERTAINMENT}

During the three year study period there were 222 cases of histologically diagnosed colorectal cancer in patients aged under 55 years in Northern Ireland. Of these, five were cases of polyposis coli and a further two patients were adopted. Of the 215 remaining probands, 10 families were uncooperative and the detailed analysis below is restricted to the 205 cases $(95 \%)$ for whom a

TABLE II Univariate log rank survival analysis of 205 index cases, for selected covariates

\begin{tabular}{|c|c|c|c|c|c|}
\hline Variable & $\begin{array}{l}\text { Observed } \\
\text { deaths }\end{array}$ & $\begin{array}{l}\text { Expected } \\
\text { deaths }\end{array}$ & $\chi^{2}$ & $d f$ & $p$ \\
\hline \multicolumn{6}{|l|}{ Sex: } \\
\hline $\begin{array}{l}\text { male } \\
\text { female }\end{array}$ & $\begin{array}{l}55 \\
67\end{array}$ & $\begin{array}{l}63 \cdot 72 \\
58 \cdot 28\end{array}$ & 2.97 & 1 & 0.08 \\
\hline \multicolumn{6}{|l|}{ Age: } \\
\hline $\begin{array}{l}<45 \text { years } \\
45-49 \\
50-54\end{array}$ & $\begin{array}{l}31 \\
36 \\
55\end{array}$ & $\begin{array}{l}29 \cdot 11 \\
34 \cdot 20 \\
58 \cdot 69\end{array}$ & 0.53 & 2 & $0 \cdot 77$ \\
\hline \multicolumn{6}{|l|}{ Duration of } \\
\hline $\begin{array}{l}\text { symptoms: } \\
<2 \text { months }\end{array}$ & 35 & $29 \cdot 01$ & & & \\
\hline $\begin{array}{l}2-5 \text { months } \\
>6 \text { months }\end{array}$ & $\begin{array}{l}43 \\
30\end{array}$ & $\begin{array}{l}49 \cdot 51 \\
29 \cdot 47\end{array}$ & $2 \cdot 50$ & 2 & $0 \cdot 29$ \\
\hline \multicolumn{6}{|c|}{ Bowel site: } \\
\hline $\begin{array}{c}\text { Proximal } \\
\text { colon }\end{array}$ & 25 & $26 \cdot 06$ & & & \\
\hline Distal colon & 41 & $41 \cdot 21$ & 0.09 & 2 & 0.96 \\
\hline \multirow{3}{*}{$\begin{array}{l}\text { Duke's stage: } \\
\text { A } \\
\text { B } \\
\text { C } \\
\text { D }\end{array}$} & 53 & $51 \cdot 73$ & & & \\
\hline & $\begin{array}{r}2 \\
39 \\
42\end{array}$ & $\begin{array}{r}8 \cdot 76 \\
66 \cdot 23 \\
29 \cdot 12\end{array}$ & $88 \cdot 3$ & 3 & $<0.0001$ \\
\hline & 31 & $\cdot 89$ & & & \\
\hline
\end{tabular}

$\mathrm{df}=$ degree of freedom
TABLE III Univariate log rank survival analysis of 205 index cases for the 'Lynch' and 'Utah' family history scores

\begin{tabular}{|c|c|c|c|c|c|}
\hline Variable & $\begin{array}{l}\text { Observed } \\
\text { deaths }\end{array}$ & $\begin{array}{l}\text { Expected } \\
\text { deaths }\end{array}$ & $\underset{\chi^{2}}{\log r a n k}$ & $d f$ & $p$ \\
\hline \multicolumn{6}{|c|}{ Lynch's cluster statistics (Z) } \\
\hline $\begin{array}{l}Z<-0.5 \\
-0.5<Z<0.0\end{array}$ & & $\begin{array}{l}43 \cdot 88 \\
48 \cdot 86\end{array}$ & & & \\
\hline $\begin{array}{l}0.0<Z<1.0 \\
1 \cdot 0<Z\end{array}$ & 15 & $10 \cdot 45$ & $3 \cdot 26$ & 3 & 0.35 \\
\hline \multicolumn{6}{|c|}{ Utah family history score $\left(\mathbf{z}^{\prime}\right)$} \\
\hline$z^{\prime}<-0.25$ & 49 & $55 \cdot 50$ & & & \\
\hline$-0.25<z^{\prime}<0.0$ & 46 & $42 \cdot 26$ & 1.91 & 3 & 0.59 \\
\hline $\begin{array}{l}0 \cdot 0<z^{\prime}<30 \\
3 \cdot 0<z^{\prime}\end{array}$ & $\begin{array}{r}8 \\
19\end{array}$ & $\begin{array}{r}6 \cdot 31 \\
17 \cdot 93\end{array}$ & & & \\
\hline
\end{tabular}

$\mathrm{df}=$ degree of freedom

family interview was possible. The crude five year survival rate of these index cases was $47 \%$.

Despite the young age of the patients, only $49 \%$ of the original index hospital charts showed evidence that a family history had been taken. These 205 probands reported a total of 1811 first degree relatives, of whom $80 \%$ were resident in Northern Ireland. On the prevalence date (1 February 1989) 569 of these relatives were dead. Excluding eight individuals killed in action during the Second World War, a death certificate was obtained for $98.6 \%$ of the remainder. For the 1242 living relatives, the vital status/medical history was verified secondarily in $98 \%$ of cases.

In all, 210 first degree relatives were reported to have suffered cancer (of any site), and this was verified in 201 (96\%). Sixty eight first degree relatives of the 205 probands were reported to have had bowel cancer. For only one of these was no verification obtained. Of the 67 remaining, the diagnosis was validated histologically in 32 (47\%), from a hospital chart in $12(18 \%)$, and from the death certificate alone in $23(34 \%)$.

The accuracy with which the cancer history of the first degree kin was reported at inteview significantly according to the primary organ affected. Deaths were judged accurately reported if the relative specified the correct International Classification of Diseases chapter. Although cancer deaths were more accurately reported as such when compared with deaths from other causes $(87 \%$ versus $70 \%, p<0.01)$, the site of the original primary tumour was accurate in only $58 \%$ of cases. Table I shows that the accuracy of the family history report of colorectal cancer tended to be higher than for other familial cancer deaths.

SURVIVAL ANALYSIS

Tables II and III show the results of the univariate log rank survival analysis. (Although the family history variable has been categorised somewhat arbitrarily for this purpose, the raw score is subsequently used in the Cox's multivariate analysis.) The only variable taken alone that was significantly predictive of survival was the pathological stage of the index tumour.

The relation between covariates was investigated using simple crosstabulations. Of the many possible bivariate associations, three were statistically significant as follows:

(1) Men had a greater proportion of rectal cancer, $\chi^{2}=8 \cdot 9, \mathrm{p}<0 \cdot 01$;

(2) Younger patients tended to have an excess 
TABLE IV Summary of the estimates of the likelihood ratio tests from Cox's proportional hazards analyses

\begin{tabular}{|c|c|c|c|c|c|}
\hline Family history $(F H)$ & Coefficient $(S E)$ & $\begin{array}{l}95 \% \text { CI for relative } \\
\text { hazard }\end{array}$ & $\chi^{2}$ & $d f 1$ & $p$ \\
\hline $\begin{array}{l}\text { (a) } \underset{\star \text { Yes } / \text { No })}{ } \text { FH/age, sex, duration, site, } \\
\text { stage }\end{array}$ & $\begin{array}{r}0 \cdot 183(0 \cdot 205) \\
-0 \cdot 150(0 \cdot 212)\end{array}$ & $\begin{array}{l}1.2(0.8-1.8) \\
0.9(0.6-1.8)\end{array}$ & $\begin{array}{l}0 \cdot 80 \\
0 \cdot 51\end{array}$ & $\begin{array}{l}1 \\
1\end{array}$ & $\begin{array}{l}\text { NS } \\
\text { NS }\end{array}$ \\
\hline $\begin{array}{l}\text { (b) Z score (Lynch cluster } \\
\text { statistic) }\end{array}$ & $0.072(0.094)$ & $1 \cdot 1(0 \cdot 9-1 \cdot 3)$ & 0.59 & 1 & NS \\
\hline $\begin{array}{l}\text { ^FH/age, sex, duration, site, } \\
\text { stage }\end{array}$ & $-0 \cdot 40(0 \cdot 102)$ & $1 \quad(0 \cdot 8-1 \cdot 2)$ & $0 \cdot 16$ & 1 & NS \\
\hline $\begin{array}{l}\text { (c) } z^{\prime} \text { Score (Utah FHS) } \\
{ }^{\star} \text { FH/age, sex, duration, site, } \\
\text { stage }\end{array}$ & $\begin{array}{r}0.025(0.046) \\
-0.042(0.050)\end{array}$ & $\begin{array}{ll}1 & (0 \cdot 9-1 \cdot 1) \\
1 & (0 \cdot 9-1 \cdot 1)\end{array}$ & $\begin{array}{l}0 \cdot 29 \\
0 \cdot 78\end{array}$ & $\begin{array}{l}1 \\
1\end{array}$ & $\begin{array}{l}\text { NS } \\
\text { NS }\end{array}$ \\
\hline
\end{tabular}

Key (a) Family history rated simply as + ve or - ve, ie presence or absence;

(b) Family history scored by the Lynch cluster statistic; ${ }^{8}$

(c) Family history scored by the Utah family history score (FHS). ${ }^{9}$

$\star F H /$ age, sex, duration, site, stage: The effect of a positive family history taking account of age, sex, duration of symptoms, bowel site and stage of tumour.

$\mathrm{NS}=$ not significant; $\mathrm{CI}=$ confidence intervals; $\mathrm{df}=$ degree of freedom.

of late stage disease (Dukes' stage C and D) $\chi^{2}=18 \cdot 3, \mathrm{p}<0 \cdot 01$;

(3) Rectal tumours accounted for a greater proportion of the advanced cancers, $\chi^{2}=12 \cdot 9$, $\mathrm{p}<0.05$.

The effect of familiality on survival is estimated in the Cox's model by the relative hazards shown in Table IV. As covariates are included in the model their possible confounding effects on the family history relative hazard are successively accounted for.

The relative hazard for familial cases is 10 to $20 \%$ higher than for non-familial cases. This is so even after accounting for age, sex, site, or duration of symptoms. When tumour stage is added to the model the excess relative hazard for familial cases disappears. This is because the familial cases tended to have later stage tumours: ( $48 \%$ of cases who had at least one affected relative had stage $\mathrm{C}$ or $\mathrm{D}$ cancers as opposed to $35 \%$ of those with no affected kin). The confidence intervals for the relative hazard include unity every case and so one must conclude that no independent effect of familiality on prognosis can be shown from these data.

\section{Discussion}

Almost 10 years ago Lunch suggested that prolonged survival was an inherent characteristic of hereditary non-polyposis colorectal cancer. ${ }^{23}$ This was on the basis of a comparison of the survival of patients from selected pedigrees exhibiting classic features of the syndrome (young age at onset, a proximal tumour excess, autosomal dominant pattern of inheritance, etc) with the American College of Surgeon's audit series. More recently, there has been recognition of how tumour genotype can affect clinical progression, ${ }^{1212}$ and hence the possibility that a knowledge of the patient's family history may improve treatment allocation. ${ }^{235} 13$

The fact that a positive family history was not an independent prognostic variable in this Northern Ireland study does not, however, necessarily negate the underlying premise. No study conducted at a single point in time can hope to capture a family's cumulative lifetime cancer risk and clearly the potential for geneenvironment interaction may render some results population specific. ${ }^{14}$
A number of other points must also be borne in mind in placing this work in context. Firstly, Lynch used crude survival estimates to infer a better prognosis in the studied pedigrees. ${ }^{23}$ Any aggregation of cases from grouped pedigrees will almost certainly comprise patients within a range of ages and periods of diagnosis and the crude proportion surviving cannot account for variations in relative survival at different ages ${ }^{15}$ or for secular trends in competing causes of death. In any case, since age, ${ }^{15}$ sex, ${ }^{16}$ and tumour site ${ }^{17}$ can all affect prognosis independently, Lynch may simply not have been comparing like with like. Comparison of survival statistics between time periods or groups is notoriously difficult when the surgeons' perceptions of suitability for resection or the proportions of all cases referred for surgery can vary. As Mecklin has intimated, ${ }^{18}$ the apparent survival advantage in the Nebraskan families may have reflected their greater fitness for radical surgery rather than any biological tumour characteristic. Whereas this study has investigated both operable and non-operable cases in a defined population, referral centres often have higher proportions of patients suitable for resection. ${ }^{19}$

A more fundamental criticism of Lynch's analysis is that the prolonged observed survival within the Nebraskan pedigrees may merely reflect earlier diagnosis and a longer lead time. Among the factors associated with prompt referral and diagnosis is advice from the immediate family, ${ }^{20}$ and people who comply with screening are more likely to know someone with a colostomy or bowel cancer. ${ }^{21}$ In view of the relatively long natural history of colorectal neoplasia, the fact that duration of symptoms was of little prognostic importance in this Northern Ireland study cannot exclude the possibility that familial cases may have a different distribution of lead times from non-familial cases. Indeed, it is possible too that Americans differ from the Northern Irish in symptom reporting behaviour and in their knowledge of the disease. In randomly selected groups of adult Americans, nearly half have gone symptomless to their doctors for an annual check up and $70 \%$ have had a digital rectal examination. ${ }^{22}$ The comparison of our results with those of Lynch is open to criticism in so far as familiality has been investigated in this study in a model free way, positing no defined underlying transmission pattern. Even with this approach, however, a relation between familiality and prognosis has been found by others. ${ }^{5}$ On the other hand, in the absence of a defined biomarker there is no definitive way to distinguish elderly sporadic patients from those who are obligate gene carriers, even within a classic cancer family syndrome pedigree.

Furthermore, as intimated by a recent population based survey of familial colorectal cancer in Utah, the methodological sophistication of segregation analysis cannot fully discount ascertainment bias in determining the clinical features of cases within a pedigree. ${ }^{23}$ Even when consonant with a pattern of autosomal dominant inheritance, it is unlikely that a single hypothesised gene is responsible for all significant colorectal cancer clusters in the population. ${ }^{33}$ No doubt aware of the growing number of putative 
oncosuppressor loci under suspicion, the same authors have acknowledged that their data could not rule out 'a much more complex underlying reality that might include polygenic components, multiple disease loci, and different levels of penetrance associated with specific alleles. ${ }^{24}$

Finally, irrespective of the technical difficulties that may lie ahead in identifying a valid biomarker, the ascertainment results of this study cast doubt on the assertion that a careful bedside history is sufficient to identify high risk families. ${ }^{25}$ Therefore, without assiduous verification from secondary sources, it is unlikely that the true prognostic importance of a positive family history will be obvious.

The authors gratefully acknowledge that the funding for this study was provided by the Ulster Cancer Foundation.

1 Wyllie AH. Human colorectal tumours: which genes confer aggression? Proc $R$ Coll Phys Edin 1989; 10: 171-82.

2 Lynch HT, Albano W, Recerbaren J, Lynch PM, Lynch JF. Prolonged survival as a component of hereditary breast and non-polyposis colon cancer. Med Hypothesis 1981; 7: 12019.

3 Albano W, Recerbaren J, Lynch HT, et al. Natural history of hereditary cancer of the breast and colon. Cancer 1982; 50: 360-3.

4 Love RR. Small bowel cancers, B-cell lymphatic leukaemia and six primary cancers with metastases and prolonged
survival in the cancer family syndrome of Lynch. Cancer 1985; 55: 499-502.

5 Kern SE, Fearon ER, Tersmette KWF, et al. Allelic loss in colorectal carcinoma. $\mathcal{F A M A}$ 1989; 261: 3099-104.

6 Armitage P, Berry G. Statistical methods in medical research (2nd ed). Oxford: Blackwell, 1987.

7 Cox DR. Regression models and life tables. $\mathscr{~} R$ Stat Soc 1972; 34: $187-220$

8 Lynch HT, Kimberling WJ, Biscone KA, et al. Familial heterogeneity of colon cancer risk. Cancer 1986; 57: 208996.
9 Williams RR, Dadone MM, Hunt SC, et al. The genetic epidemiology of hypertension: a review of past studies and current results for 948 persons in 48 Utah pedigrees. In: Rao
DC, Elston RC, Kuller LH, et al, eds. Epidemiology of coronary heart disease: past, present, and future. New York: Alan Liss, 1984

10 Hunt SC, Williams RR, Barlow GK. A comparison of positive family history definitions for defining risk of future disease. f Chron Dis 1986; 39: 809-21.

11 Berry G. The analysis of mortality by the subject-years method. Biometrics 1983; 39: 173-84.

12 Dulbeccio R. Cancer progression: the ultimate challenge. $\operatorname{lnt} \mathcal{F}$ Cancer 1989; Suppl 4: 6-9.

13 Vile R. Tumour suppressor genes. BMF 1989; 298: 135-6.

14 Weiss KM, Schull WJ. Identifying groups at high risk of colorectal cancer. In: Ingall J, Mastromarino AJ, eds. Prevention of hereditary large bowel cancer. New York: Alan Liss, 1983.

15 Cancer statistics. Incidence, survival and mortality in England and Wales. Studies on Medical and Population Subjects, No. 43 London: OPCS and the Cancer Research Campaign, 1981.

16 Enblad P, Adami H-O, Bergstrom R, Glimelius B, Krusem $\mathrm{U}$, Pahlman L. Improved survival of patients with cancers of the colon and rectum? FNCI 1988; 80: 586-91.

17 Halvorsen TB, Seim E. Tumour site: a prognostic factor in colorectal cancer? A multivariate analysis. Scand $\mathcal{f}$ Gastroenterol 1987; 22: 124-8.

18 Mecklin J-P, Jarvinen HJ. Clinical features of colorectal carcinoma in cancer family syndrome. Dis Colon Rectum carcinoma in cance

19 Clarke DN, Jones PF, Needham CD. Outcome in colorectal carcinoma: seven year study of a population. $B M \mathcal{F} 1980$ 280: 431-5.

20 MacArthur $\dot{C}$, Smith A. Factors associated with speed of diagnosis, referral and treatment in colorectal cancer. $f$ Epidemiol Community Health 1984; 38: 122-6.

21 Farrands PA, Hardcastle JD, Chamberlain J, Moss S. Factors affecting compliance with screening for colorectal cancer. Community Med 1984; 6: 12-19.

22 Cancer of the colon and rectum: summary of a public attitude survey. CA 1983; 33: 359-65.

23 Cannon-Albright $\mathrm{L}$, Thomas TC, Bishop T, Skolnick MH Burt R. Characteristics of familial colon cancer in a large Burt R. Characteristics of familial colon cancer

population database. Cancer 1989; 64: 1971-5.
24 Cannon-Albright LA, Skolnick MH, Bishop T, Lee R, Burt R Common inheritance of susceptibility to colonic adenomatous polyps and associated colorectal cancers. New EnglF Med 1989; 319: 533-7.

25 Weber W, Voegtli B, Buser M, et al. Vergleich der tumorinzidenz bei 251 verwandten ersten grades von 50 patienten mit kolorektalen karzinomen mit derienigen ser basler bevolkerung. Schweiz Med Wschr 1985; 115: 1005-6. 